\title{
Influence of Fine Bubble Generator Architecture on Time Variation of Dissolved Oxygen Concentration in Water
}

\author{
NICOLAE BARAN ${ }^{2 *}$, MIHAELA CONSTANTIN ${ }^{1}$, BEATRICE TANASE ${ }^{1}$, EDGAR MORARU ${ }^{2}$, CORINA IOANA MOGA ${ }^{3}$ \\ 'Politehnica University of Bucharest, Department of Engineering Thermodynamics, 313 Splaiul Independentei 060042, Bucharest, \\ Romania \\ 2Politehnica University of Bucharest, Department of Mechatronics and Precision Mechanics, 313 Splaiul Independentei, 060042 , \\ Bucharest, Romania \\ ${ }^{3}$ DFR Systems SRL, 46 Drumul Taberei, 061392, Bucharest, Romania
}

\begin{abstract}
The paper presents two constructive solutions in the field of fine bubble generators that serve to aerate the water. Two installations for experimental researches have been designed and built in connection with the two constructive solutions. The dissolved oxygen concentration was experimentally determined. The theoretical and experimental results for the two constructive solutions are compared showing a good coincidence in relation to the results reported in the literature.
\end{abstract}

Keywords: water aeration; fine bubbles generator; dissolved oxygen concentration

Water aeration is necessary to improve water quality to avoid the oxygen deficiency in systems where there is a biochemical oxygen demand.

The main purpose of water aeration, irrespective of the industry and the reason it is used, is to increase or maintain an oxygenated level of dissolved oxygen in a water volume.

Recent researches on interfacial mass transfer with fine bubble generation focuses on the study of the following topics: porosity (free volume or fraction of voids) [1,2], bubble characteristics [3,4], flow determination, and computer fluids dynamics studies [5,6], heat transfer measurements [7,8], mass transfer studies [9].

In studies on gas diffusion in liquids and hydrodynamic behavior of bubble columns, it was concluded that bubble size values depend primarily on the physicochemical properties of the liquid phase and on how the air distribution is achieved [10].

The oxygen required for the aeration process is taken from the atmospheric air and introduced into the water. For this aeration to be effective, uniform air dispersion must be ensured across the entire water body in the tank or basin. For the dispersion of air in the water, fine bubble generators (FBG) [11] or porous diffusers constructed of ceramic or elastic materials [12] are used.

The paper presents a comparison between two types of fine bubble generators (FBG).

The first type of generator is made of ceramic materials; this type of generator is known in the literature [13] as a porous ceramic diffuser.

The second type of generator is a generator in which the perforated plate is made by unconventional technological processes [14]: chemical corrosion processing.
The main conclusion is that the porous ceramic diffuser is more advantageous than the fine bubble generator at which the orifice plate is made by chemical corrosion because it ensures a faster oxygenation of the water mass.

\section{Experimental part}

Materials and methods

The equation which defines the transfer speed of the $\mathrm{O}_{2}$ from air in water is [15]:

$$
\frac{d C}{d \tau}=a \varepsilon_{\bar{q}}\left(C_{s}-C\right)\left[\frac{\mathrm{kg} 1}{\mathrm{~m}^{3}} \frac{1}{s}\right]
$$

where:

$d C / d \tau$-The transfer speed of dissolved oxygen in water; $a k_{L}$-Volumetric mass transfer coefficient $\left[\mathrm{s}^{-1}\right]$;

$C_{s}$-Mass concentration of oxygen in water at saturation $\left[\mathrm{kg} / \mathrm{m}^{3}\right]$; $\mathrm{m}^{3}$.

C-Current mass concentration of oxygen in water [ $\mathrm{kg} /$ The term ak include:

a -interphase contact specific surface:

$$
a=\frac{A}{V}\left[\frac{m^{2}}{m^{3}}\right]
$$

where:

A -gas bubbles area [ $\left.\mathrm{m}^{2}\right]$

$V$-biphasic system volume (air plus water) [ $\left.\mathrm{m}^{2}\right]$

$k_{L}$-the coefficient of mass transfer $\left[\mathrm{kg} / \mathrm{m}^{3}\right]$

\begin{tabular}{|c|c|c|}
\hline The purpose & Theoretical solution & Practical solution \\
\hline The increase of $a$ & The decrease of the gas bubble diameter & $\begin{array}{c}\text { The decrease of the } \\
\text { F.B.G. orifices diameter }\end{array}$ \\
\hline The increase of $k_{L}$ & The turbulence enhancement & - \\
\hline The increase of $C_{5}$ & $\begin{array}{c}\text { The increase of the } \mathrm{O}_{2} \text { concentration into } \\
\text { the water }\end{array}$ & - \\
\hline The increase of $C_{0}$ & $\begin{array}{c}\text { Minimum } C_{0} \text { values depending the } \\
\text { existing microorganisms nature into water }\end{array}$ & $\begin{array}{c}\text { Introducing air, oxygen } \\
\text { and } \mathrm{O}_{3} \text { into water }\end{array}$ \\
\hline
\end{tabular}

Table 1

SOLUTIONS TO INCREASE $\mathrm{dC} / \mathrm{d} \tau$

Phone: 0214027900 
From equation (1) one can notice that to increase the transfer speed $\mathrm{O}_{2}$ to water, the following are required:

I. the increase of $\mathrm{k}_{\mathrm{L}}$ and $\mathrm{C}_{\mathrm{s}}$

II. the decrease of $C$.

The conditions I and II are given in table 1 .

Equation (1) indicates the modification of oxygen concentration in time, as a result of molecular diffusion of $\mathrm{O}_{2}$ from the area with high concentration to the area with low $\mathrm{O}_{2}$ concentration.

\section{Results and discussions}

Elastic membrane porous diffuser from E.P.D.M.

The porous diffuser consists of two elements: elastic membranes (2) (fig. 1) which is threaded by the diffuser $\operatorname{body}(1)$.

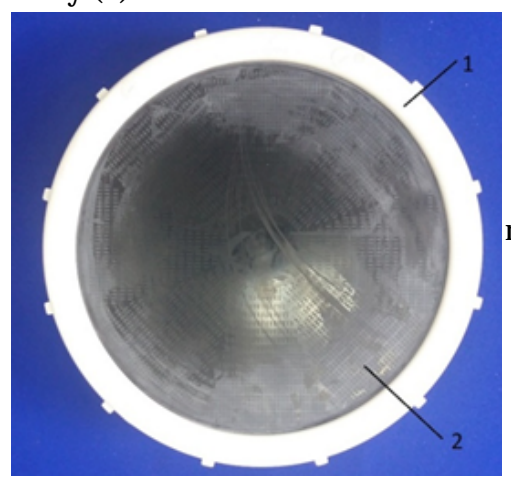

Fig. 1. General view of the porous diffuser: 1 - elastic membrane fastening ring; 2 elastic membrane

The elastic membrane contains more than 1000 rectangular shaped orifices; a single orifice was measured using a modern OLYMPUS BX51M microscope.

The dimensions of the orifice, approximated as a rectangle, are: $L x \mid=735.03$ x $128.29=94296.998 \mu m^{2}$.

The equivalent diameter of the orifice will be:

$d_{\varepsilon}=\frac{4 A}{P}=\frac{4.94296 .998}{2(735.03+128.29)}=218.45 \mu \mathrm{m}=0.21845 \mathrm{~mm}$

The value of this diameter falls within the operating range of bubble generators, which emitfine bubbles.

During the experimental researchesfor the two constructive solutions, the following values were kept constant:

- the volume flow of air instilled in water: $600 \mathrm{dm}^{3} / \mathrm{h}$

Table 2

VALUES OF DISSOLVED OXYGEN CONCENTRATION IN

WATER FOR POROUS MEMBRANE DIFFUSER E.P.D.M.
- hydrostatic load: $\mathrm{H}=500 \mathrm{mmH}_{2} \mathrm{O}$;

- water temperature: $t=23^{\circ} \mathrm{C}$, corresponding to the water temperature, from [16] the saturation concentration was chosen: $C_{\mathrm{s}}=8.6 \mathrm{mg} / \mathrm{dm}^{3}$.

- initial concentration of dissolved oxygen in water: $\mathrm{C}_{0}=$ $5.10 \mathrm{mg} / \mathrm{dm}^{3}$.

As a result of the measurements, data from table 2 were obtained. [17].

The obtained results are similar to those in the literature

Fine bubble generator made by modem micro technologies

By chemical corrosion was made in silicon pads of $390 \mu \mathrm{m}$ thickness, some orifices with a diameter of less than $1 \mathrm{~mm}$ that provide an efficient oxygenation of the water.

Figure 2 shows 8 silicon plates with orifices having the geometry shown in figure 3 .

The figure shows:

$$
\operatorname{tg} \alpha=\frac{B C}{B A}=\frac{219.97}{390}=0.5640^{\circ}
$$

The equivalentdiameter $\left(d_{\mathrm{e}}\right)$ of an orifice is calculated with the relation:

$$
d_{e}=\frac{4 A}{P}
$$

where:

A - area of the flow section $\left[\mathrm{m}^{2}\right]$;

$P$ - the wet perimeter [m].

The exitsection being a square with side of $\mathrm{a}=629.795 \mu \mathrm{m}$ gives:

$$
d_{\varepsilon}=\frac{4 a^{2}}{4 a}=a=629.795 \mu m=0.629795 \mathrm{~mm}
$$

The technology used for processing the silicon wafer is called bulk micromachining, allowing the material to be processed, the HF corrosion substance, and the photoresist mask material.

Figure 5 shows the scheme of the experimental plant. The main element is the FBG, which has square orifices with a $629.795 \mu \mathrm{m}$ side, made by chemical erosion.

For a certain hydrodynamic regime, using the rotameter (6) the gas flow rate instilled in water was measured: $\dot{\mathrm{V}}=600 \mathrm{dm}^{3} / \mathrm{h}$.

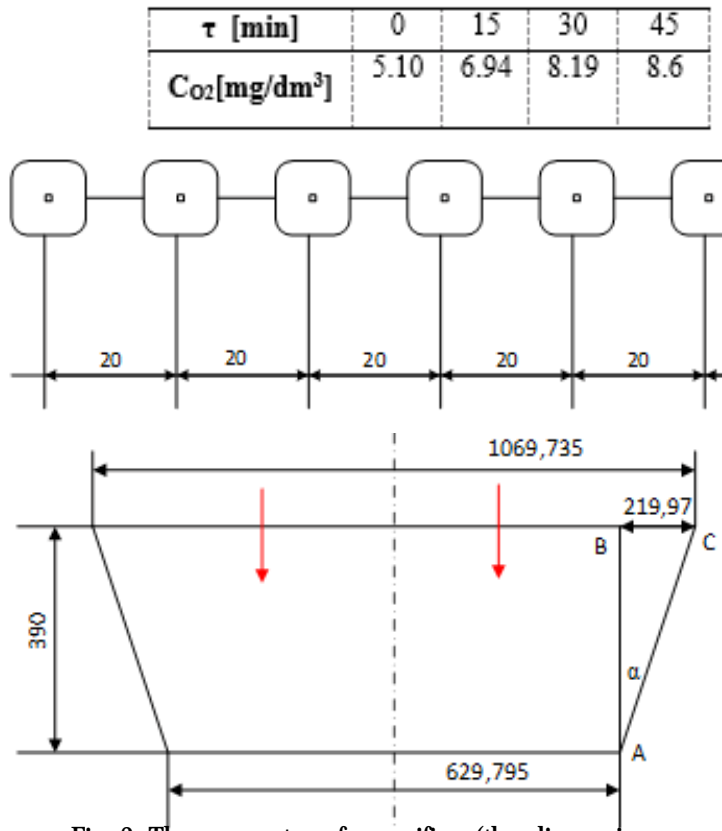

Fig. 3. The geometry of an orifice (the dimensions are in $\mu \mathrm{m}$ )
Fig. 2. The location of the eight cells of fine bubble generation (the dimensions are in $\mu \mathrm{m}$ )

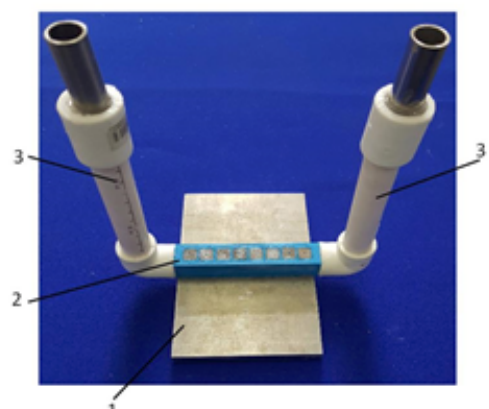

Fig. 4. General view of the fine bubble generator: 1 - support plate; 2 - fine bubble generator body; 3 - compressed air supply pipes 

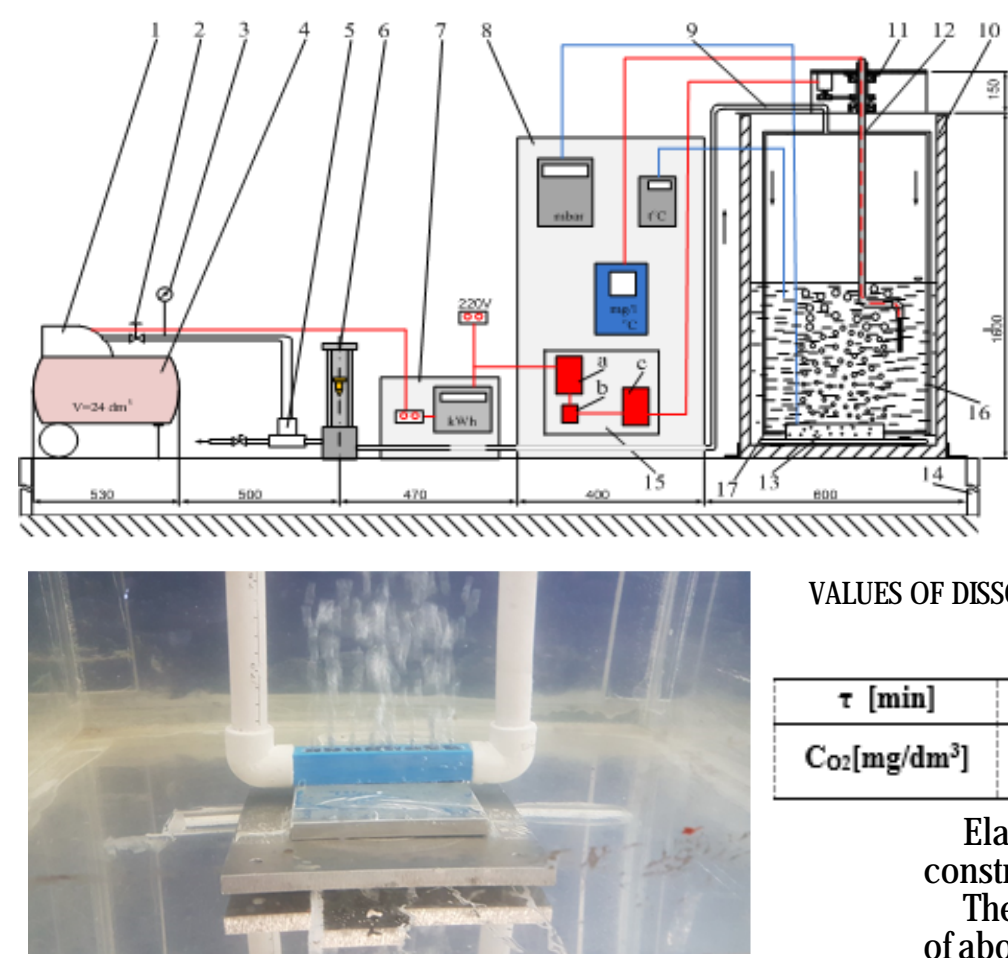

Fig. 6. Fine bubble generator in operation

The tank (10) has the dimensions $|\times| \times h=0.5 \times 0.5 \times 1.6$ $=0.4 \mathrm{~m}^{3}$; the water layer above the FBG has a height of $\mathrm{h}=$ $0.5 \mathrm{~m}$ and a volume of $0.5 \times 0.5 \times 0.5=0.125 \mathrm{~m}^{3}$.

Initial operating data (FBG): $\dot{\mathrm{V}}=600 \mathrm{dm}^{3} / \mathrm{h}, \mathrm{t}=23^{\circ} \mathrm{C}, \mathrm{C}_{\mathrm{s}}$ $=8.6 \mathrm{mg} / \mathrm{dm}^{3}, \mathrm{C}_{0}=5.10 \mathrm{mg} / \mathrm{dm}^{3}$

Figure 6 shows the operation of the fine bubble generator.

The experimental results from the measurements are given in table 3.

For both constructive versions, during the experimental researches were kept constant:

- the volume flow of air instilled in water: $600 \mathrm{dm}^{3} / \mathrm{h}$

- the water temperature: $t=23^{\circ} \mathrm{C}$;

- the concentration of dissolved oxygen in water at $\tau=0$,

$\mathrm{C}=5.10 \mathrm{mg} / \mathrm{dm}^{3}$.

Figure 7 presents the variation of oxygen concentration in water.

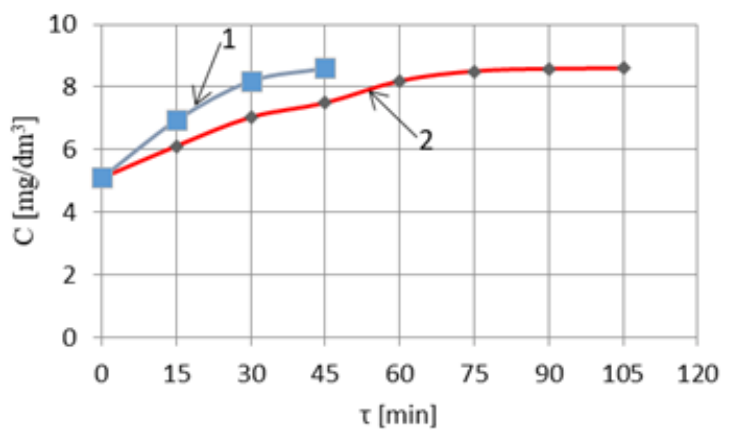

Fig. 7. The variation in time of oxygen concentration in water:

1 - for porous membrane diffuser E.P.D.M, 2- for FBG with silicon plates

Figure 7 shows the following:

- the dissolved oxygen concentration in water increases faster in the case of the porous diffuser; Because the value of the specific interphase contact area (a) is higher.

- the time to reach the mass concentration of oxygen saturation in the porous diffuser is reduced by 2.3 times compared to the FBG.
Fig. 5. Sketch of the experimental plant for researches regarding water oxygenation: 1-electro compressor with air tank; 2- pressure reducer; 3-manometer;

4-compressed air tank $\mathrm{V}=24 \mathrm{dm}^{3}$; 5-T-joint; 6-rotameter;

7-electrical panel; 8- panel with measuring devices;

9- pipe for the transport of the compressed air to the

FBG; 10-water tank; 11- mechanism for the probe actuation; 12-oxygen meter probe; 13-FBG;14- installation holder; 15-electronics control: a- supply unit, b- switch,

c- control element; 16, 17-FBG supply lines with compressed air

Table 3

ALUES OF DISSOLVED OXYGEN CONCENTRATION IN WATER FOR FBG WITH SILICON PLATES

\begin{tabular}{|c|c|c|c|c|c|c|c|c|}
\hline [min] & 0 & 15 & 30 & 45 & 60 & 75 & 90 & 105 \\
\hline $\mathrm{Co}_{02}\left[\mathrm{mg} / \mathrm{dm}^{3}\right]$ & 5.10 & 6.12 & 7.04 & 7.50 & 8.20 & 8.51 & 8.59 & 8.60 \\
\hline
\end{tabular}

Elastic membrane porous diffusers have a simple construction, increased reliability in operation.

The orifices of the perforated membrane have a diameter of about $0.21 \mathrm{~mm}$, which ensures the dispersion of the fine air bubbles $(\varnothing \approx 1 \mathrm{~mm})$.

Porous diffusers with E.P.D.M. membranes have a high aging duration, are resistant to ozone, and the diffuser body is made of shock-resistant plastics. For elastic membrane diffusers, the orifices closes when the air stops.

Porous diffusers do not require maintenance because the membrane vibrations lead to self-cleaning of the active surface.

The disadvantages of porous diffusers are:

- emit bubbles of different sizes;

- does not ensure a uniform dispersion of air in a water volume.

Making fine bubble generators with advanced technologies ensures a uniform distribution of air in a volume of water; at the same time the size of the air bubbles will be the same $[18,19]$.

FBG constructed with silicon plates is an alternative to other air-dispersing processes in water [20,21].

\section{Conclusions}

A technical solution for making orifices in silicon pads has to be economically analyzed.

The use of silicon pads with orifices of various shapes will make it possible to extend research in the field of water aeration. found:

Following experimental research, the following was

- for the same air flow rate in water and the same hydrostatic load $\mathrm{H}=500 \mathrm{mmH}_{2} \mathrm{O}$, the aeration time $\left(C_{0} \rightarrow C_{s}\right)$ is reduced from 105 'in case of FBG to $45^{\prime}$ for the porous diffuser.

The advantage of the porous diffuser compared to FBG is that the rates of oxygen transfer to water increases because it increases the interfacial specific area (a).

The growth of $a$ is due to the fact that at the same volumetric flow rate, the porous diffuser with several orifices $\varnothing 0.21 \mathrm{~mm}$ generates more air bubbles so a will increase.

The final conclusion is that the generation of smaller and more numerous bubbles lead to the improvement of the water aeration process. 
Acknowledgment: This work was supported bya grant of the Romanian National Authority for Scientific Research and Innovation, CCCDI UEFISCDI, projectnumberManunet-MNET17/ENER2307-CEBIOTREAT, within PNCDI

\section{References}

1.BOUAIFI, M., HEBRARD, G., BASTOUL, D., ROUSTAN, M., Chem. Eng. Process, 40, 2001, pp. 97-111.

2.TANG, C., HEINDEL, T.J ., Chem. Eng. Sci., 59, 2004, pp. 23-32.

3.PRAKASH, A., MARGARITIS, A., LI H., Biochem. Eng. J, 9, 2001, pp. 55-63. 4.LAPIN, A., PAASCHEN, T., JUNGHANS, K., LU“BBERT, A., Chem. Eng. Sci., 57, 2002, pp. 19-24.

5.DEGALEESAN, S., DUDUKOVIC, M., PAN, Y., AIChE J , 47, 2001, pp. 13-31. 6.DHOTRE, M.T., EKAMBARA, K., JOSHI, J.B., Exp. Therm. Fluid Sci., 28, 2004, pp. 17-21.

7.LI, H., PRAKASH, A., Chem. Eng. J, 2001, 79, pp. 717-25.

8.CHEN, W., HASEGAWAT., TSUTSUMI A., OTAWARAK., SHIGAKI Y., Chem. Eng. J, 96, 2003, pp.37-44.

9.VANDU, C.O., KRISHNA, R., Chem. Eng. Process, 43, 2004, pp.87-95. 10.MOUZA, A.A., DALAKOGLOU, G.K., PARAS, S.V., Chemical Engineering Science, 60, 2005, pp.1465 - 1475.

11.OPRINA G.,PINCOVSCHI I., BARAN GH., Hidro-gazo-dinamica sistemelor de aerare echipate cu generatoare de bule, Editura POLITEHNICA PRESS, Bucuresti, 2009

12.ROBESCU, D., ROBESCU, D.L., Procedee, instalatii si echipamente pentru epurarea fizica a apelor uzate, Editura BREN, Bucharest, 1999.
13.GEORGESCU, S.G., Evolution d'une bulle: formation a partir d'un orifice et eclatement a la traversée d'une surface libre, PhD thesis, Institut Politechnique de Grenoble, 1999.

14.BERCE, P., BALC, N., CAIZAR, C., PACURAR, R., SEVER, A., BRATEAN, S., FODOREAN, I., Tehnologii de fabricatie prin adaugare de material si aplicatiile lor, Editura Academiei Romane, Bucharest, 2014.

15.PATULEA, AL. S., Influence of functional parameters and fine bubble generator architecture on aeration plants efficiency, PhD thesis, Universitatea Politehnica Bucuresti, 2012.

16.CALUSARU, I.M., The influence of liquid physical properties on the oxygen processes efficiency, PhD Thesis, Universitatea Politehnica Bucuresti, 2013

17.PATULEA, AL., CALUSARU, I. M., BARAN, N., Advanced Materials Research, Trans Tech Publications, Switzerland, 550 - 553, 2012, pp 3388 $-3394$.

18.J INESCU, V., PETRESCU, S., JINESCU, C., Rev. Chim.(Bucharest), 64, no. 6, 2013, p. 630-638.

19.CRIVINEANU, M. F., DUMITREL, G.A., PERJU, D.S., J INESCU, C., NEGREA, A., Rev.Chim.(Bucharest), 63, no. 10, 2012, p. 1051- 1055.

20.IONESCU, G. L., DONTU, O., GLIGOR, E., UPB Sc.Bull., Series C, 77, Iss.3, 2015, p.305-314

21.BESNEA D., DINU E., AVRAM M., SPANU A., CONSTANTIN V., PANAIT I.C., Additive technologies for realization of microfluidic systems, The 8 th International Conference on Advanced Concepts in Mechanical Engineering, ACME 2018, lasi, Romania.

$\overline{\text { Manuscript received: 26. 04.2018 }}$ 